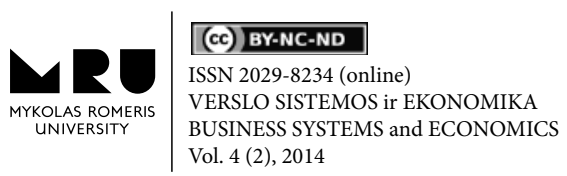

\title{
THE DICHOTOMY OF SELF-ACTUALIZATION AND SELF-TRANSCENDENCE
}

\author{
Ramūnas VANAGAS \\ Mykolas Romeris University \\ Ateities str. 20, LT-08303 Vilnius, Lithuania \\ E-mail: rvanagas@mruni.eu \\ Adomas Vincas RAKŠNYS \\ Mykolas Romeris University \\ Ateities str. 20, LT-08303 Vilnius, Lithuania \\ E-mail: e_cnv@yahoo.com
}

doi:10.13165/VSE-14-4-2-07

\begin{abstract}
This article focuses on the classical A. H. Maslow's motivation conception and aims to synthesize the logic of this theory with F. Taylor and M. Weber's management theories, justifying the significance of Maslow's motivation theory as an instrument used for forming organizational culture and values which will be gained by members of the staff. The second part of this article discusses the problem which is related with the most important elements of Maslow's theory: the highest individualistic self-actualization element and altruistic, more spiritual selftranscendence alternative, and purposes on crystallizing implications of these elements for organizations' managers enabling to identify these characteristics in staff members and also evaluate benefits of both elements considering specifics of organization's field.
\end{abstract}

Keywords: self-actualization, self-transcendence, hierarchy of needs, motivation, Maslow. JEL classification: M12, M14, M54.

\section{Introduction}

Regardless of the field activities of an organization, practical significance of human motivation and motivational systems are definite. A judicious motivation of employees is an essential parameter for seeking organizational purposes and ensuring successful working behavior in both small companies and international business corporations that are run under competitive and permanently changing circumstances. However, in practice, according to the pluralism of motivational systems, its complexity and diverse rhetorical noise, which covers principles of motivational theories, it is difficult for line managers or human resource generalists to choose optimal motivational methods. It is worth mentioning that every theory, depending on academic's already shaped philosophical postures, implies a set of certain forms of values and thinking. Motivational theories based on a naturalistic 
perspective highlight individual need of power, recognition and strong leadership, as well as higher level of responsibility, competition and self-actualization as the highest individualistic aspect (Hiriyappa, 2009). Self-actualization focuses on the revelation of the human's inner potency and other individuals becoming only means to reach one's goals. An idealistic direction reveals the highest motivational level as self-transcendence, orientation to the others, pushing personal limits, focusing on the importance of understanding, spirituality and tolerance. As F. Nordin (2009, p. 1654) notices, "because of their fundamental concern for transcendental motivations and self-transcendence, transcendental marketers will always look after the interest of their customers, based on the desire to serve". The dualism of these attitudes in the organizational context provides two possible alternative motivational directions. Therefore, according to the authors, there is a problem seeking to identify which direction of motivational values might be the priority and dominate in a modern business discourse. A very popular and easy adaptable theory of A. H. Maslow's hierarchy of needs was chosen to justify the problem of the article. Within the structure of the theory, the compatibility of self-actualization and self-transcendence with concerns of private sector may be analyzed. In a historical context of the article, management models will be analyzed within both private and public sectors, revealing that the logic of the hierarchy of needs was consolidated long before it assumed a systemic attitude in Maslow's research. It was embedded in the theory of scientific management, in Taylor's conception, as well as in the structure of Weber's traditional bureaucratic organization. The theme of the article is relevant for business executives, by giving an additional historical background through the context of motivational instruments, to form valuable and cultured environments, business model strategies and, of course, to raise the leaders who have qualities of self-actualization and self-transcendence in the organizational structure. According to the theoretical insights in the article, the leaders have a possibility to encourage staff members to treat customers conscientiously, to co-ordinate personal and organizational goals through motivation, improve job satisfaction, simultaneously improving indicators of quality and productivity of a specific activity and reacting quickly towards the goals in the private sector, which is influenced by tendencies of globalization in the socio-cultural environment. The research of the topic is based on the analysis of literature.

\section{Logic of Maslow's Hierarchy of Needs in Taylor and Weber's Conception}

Analyzing the genesis of motivational theories, it becomes obvious that most of motivational systems are related to the 20th century scientists, especially highlighting the input of the United States' academics. However, it is important to perceive that the logic of Maslow's theory conception can be found in the studies of former writers in the field of management and administration. The authors of the article, who performed analysis of certain traditional management models, seek to demonstrate that Maslow's conception is historically deeply embedded within intersectional organizational behavior. It is necessary to change attitude and to look for novel, alternative methods by re-integrating well-established motivational methods under the technological, economical, political and valuable changes. The purpose of this paper is to show that a motivational system may be not only a methodology to raise staff's motivation, but also a tool to form organization's structure, priorities, philosophy, strategy, culture and other attributes. Maslow's theory of hierarchy of needs is based on the classification of the interdependent human needs by distinguishing the physiological needs, safety needs, love and 
belongingness, as well as the esteem needs and self-actualization (Maslow, 1943). Seeking to ground the importance and adaptation of Maslow's theory, writers decided to analyze F. W. Taylor's principles formed by the classical scientific management in the United States. These principles are based on partial motivational components, emphasizing the significance of cooperational links between managers and workmen, and on a results-based pay, on training and development in terms of efficiency and on better assurance of workplace safety (Taylor, 1911). Even though Taylor's conception mechanized a person, a workman is considered to be as mechanism, in order to improve its efficiency in terms of time and quality without possibility to take the personal initiative, blowing the lid off potential of human creativity, Taylor's model reflects certain disposition of human needs, which can be found in Maslow's later conception. Results-based payment provides a possibility for a person, who wishes to work, to satisfy the physiological needs. An assurance of workplace safety is concurrent to Maslow's theory that humans, according to the evolutionary imperative, should feel safe in their personal surroundings. The third Taylor's aspect, which might be important to us from the motivational point of view, stresses co-operation and permanent link between managers and workmen by instructing and coordinating them. Though it is necessary to stress that communication between managers and workmen is based on pragmatic reasons, basically, it can be asserted that this principle partly satisfies the third Maslow's communication need. It is worth mentioning that in Taylor's model, the possibility is created to satisfy the need of selfesteem within work motivation context. One of the possible components of the satisfaction of self-esteem is a principle of labor productivity, which is oriented towards the result and based on a higher salary. Of course, the salary assures the satisfaction of not only physiological needs, but it also creates a possibility to get an exceptional status within colleagues by becoming more efficient than other workers, and also by increasing a possibility to reach self-satisfaction in respect of self-esteem.

It is important to understand that Taylor's conception is not the only one example, which unfolds that motivational components were organically embedded in the elements of organization structures within the principles of organizational activity. Another remarkable Maslow's theory logic a priori is found in the traditional German management of the 20th century, also in Weber's (1978) bureaucratic conception in the context of public administration. From the motivational point of view, the important element of a bureaucratic organization is a permanent salary, which does not depend on results, but on higher qualification of an employee. In Maslow's motivational system, the first factor is physiological factor, which means that if you want to satisfy this factor, salary plays a very important role, whereas a traditional public administration model not only meets the requirement, but also guarantees the stability. There is no direct responsibility for the activities performed by the career civil servants in this way, nothing but increasing qualification assures changes in finances. Based on the logic of traditional model, there is an opportunity to have a permanent workplace until retirement at public administration institutions, thus, creating a feeling of stability and comfortability. The second level of Maslow's needs theory points to the factor of security. Traditional Weber's structure allows satisfying this need by providing permanent workplace and wide spectrum guarantees. A bureaucratic mechanism is designed in such a way that the civil servant not only gets a permanent workplace, but also gets legally regulated career perspectives. The third point in Maslow's theory of hierarchy of needs is the need of love and belongingness. According to a structure of the traditional public administration model, excluding the aspect of bureaucracy and depersonalization, the civil servant is identified with the institution, thus, 
it can be affirmed that the logic of model determines satisfaction of the person's need. The civil servant is considered to be a part of a complicated bureaucratic apparatus, which guarantees the implementation of public policy, thus, it can be affirmed that looking from outside, the servant and the institution are in unison. On the other hand, the Weber-like principles were focused on the fact that the civil servant would acquire a specific status with regard to other community members. Thus, it was intended to ensure that the leader primarily will focus on the public interest. A specific status of the civil servant, with regard to other community members, is related to the fourth need of self-esteem in Maslow's hierarchy of needs classification. In civil service, to be called as in a privileged area, appropriate conditions are created for an individual to satisfy the need of self-esteem.

Summarizing it can be said that although the particularity of private and public sectors is different, both in Taylor's and Weber's conceptions it was possible to find the components of Maslow's hierarchy of needs. One of the key differences in Taylor's model is that salary depends on results, therefore, there is a great possibility of self-made clear and rapid financial increment, but it also implies a possibility of regression because of declining work performance the salary may decrease as well, thus, it can cause a threat to optimal satisfaction of the physiological needs. On the other hand, a Weber-like democracy is much more advanced, the salary does not directly depend on the results, but in order to gain higher qualification, the requirements increase and it is not easy to achieve it like in Taylor's model. However, in both concepts the worker's safety assurance is emphasized, but from Taylor's point of view, it focuses only on safe working conditions, thus, a Weber-like bureaucracy, from the point of Maslow's safety factor view, is richer because it does not only guarantee safe working environment, but also provides various social benefits and permanent workplace. Taylor's model stresses the importance of development and training, from the motivational point of view, it can be bracketed to the career perspectives of the Weber-like principles. By comparing the two conceptions, it is important to understand that two different sectors are analyzed, which note opposite characteristics of management theory, whereas the main similarity of both models could be the impersonalization of individual by revivifying him to the mechanism that does not have any unique and individual performance. Therefore, by applying logic of theory of Maslow's hierarchy of needs, the writers intentionally neglected the highest factors of self-actualization or self-transcendence, because self-actualization and self-transcendence are focused on the revelation of the individual's best qualities, in case of self-actualization, it focuses on the revelation of human's individual, creative and personal potential, whereas selftranscendence, by trespassing the highest level of personal boundaries, focuses on a meaning, value or other objects. Modern times organizations, such as Weber-like bureaucracy and Taylor's scientific management theory, completely neglect these very important factors that in post-modern times may become the guarantee of luck and profit. Paradoxically, however, in the context of modernism the leadership training for an ordinary employee was not in focus, whereas in post-modern times the leaders of self-actualization and self-transcendence become the key components who generate ideas, inspire staff members by having innovative and modern ideas, who are able to create moral work environment and form high standards based on organizational culture. Therefore, because of change of life and intellectual forms, it is necessary to develop and exploit motivational techniques by adapting to the needs of modern society. It is no longer enough to satisfy only the basic needs of individual in organizations in these post-modern times. To this end, in the second part of article, the analysis and evaluations of the aspects of self-actualization and self-transcendence will be carried out. 


\section{The Dilemma of Self-Actualization and Self-Transcendence}

In the first part of the article, it was revealed that the classical management theory contained many parameters of Maslow's theory of motivational hierarchy of needs, except the uppermost factors. It is necessary to understand that modern challenges of globalization determine the fact that organizations have to change constantly, to integrate and combine various theoretical models, to use their staff as the most important company resource. Under constant competitive conditions, nobody relies on the only one framework or single style of leadership, thus, methods of centralization and decentralization are combined as well as charismatic and autocratic leadership styles. The same logic is relevant in the analysis of the highest factors of Maslow's motivational conception. Although, from the very first view, it can seem that self-actualization and self-transcendence are incompatible, an absolute opposition, the writers of the article argue that on the contrary self-actualization and self-transcendence can be compatible together, yet this compatibility might be very useful. Of course, the fact that the most important thing is to ensure the basic needs of individuals has to be taken into consideration. Salary, safe working conditions, strong social connections and high level of staff's self-esteem could be practical investment for the managers of the organizations to create an opportunity to unfold the highest human qualities.

The first argument is related to the motivational factor of self-actualization. Selfactualization is directed towards revelation of personal potential (Maslow, 1972). Self-actualizing workers distinguish themselves by having higher winning ambitions, higher tolerance level of competition, and the development of personal skills. This factor is most commonly associated with the Western culture and its individualism. On the one hand, the individuals, who have these traits, become good leaders, because they are able to capture people's attention. As Tayeb (2004) stresses, a link which exists between people from more developed by economic means countries, where individualistic needs dominate, comparing to the collective societies in less advanced countries. His argument implies that people with higher personal goals are likely to seek greater economic prosperity and recognition, relying on selfconfidence, whereas in collective societies the prerogative is granted to community, group or family, where achievements are considered to be a merit and responsibility of the group. On the other hand, as Wright (2009) notes, the workers with a dominating winning need are not necessarily good leaders, because there is a possibility that the same high standards, which they apply to themselves, they will try to apply to their subordinates, but the staff simply will not have enough human resources to reach their level as well as to perform demanding tasks. As an investigation performed in Australia showed (Henry, 2006, p. 170-180), managers of organizations should understand that the potential of self-actualization may be not necessarily directed towards work motivation, but it can be realized within life domain. That is why it is very important to provide insight into early identification of worker's capabilities. On the other hand, scientists D. B. Wolfe and R. Sisodia (2003) treat self-actualization as a natural process, concurrent to the age of an individual. According to them, only the individual, who reaches the forties, starts the process of self-actualization. However, contrary to the authors, it is necessary to point out that there is a difference between identity, social and personal maturity and self-actualization, as Maslow (1972) treats, highlighting the aspects of uniqueness that can occur at early age.

The second very important factor, which every leader should know, in regards of workers seeking for self-actualization, is that the leaders should provide better conditions for 
autonomy, enabling the workers to commit the responsibility and unfold their unique traits (Assor and Oplatka, 2003). Of course, there are more obstacles within academic discourse that could prevent an individual from reaching self-actualization. "Comprehensive list of barriers includes: scarcity of goods/rewards, failure to satisfy basic needs, antisynergic organizational regulations/laws, things that increase anxiety, loss or separation of any kind, forcing change on the fearful, bad communication, suspicion, denial of truth" (Payne, 2000, p. 221).

The third important factor is that the person seeking for self-actualization, taking into account individual characteristics, should be a subject to higher creativity, more responsibility demanding targets, but it is also important to understand that this is exactly the person who seeks self-actualization. This implies that if the individual is not able to satisfy his growing needs, he will regress down, the lower level needs will become stronger and regressive frustration may happen (Alderfer, 1972). It may not be beneficial for the leaders, because the worker may want to receive higher salary or certain privileges. According to M. A. Crumpton (2013, p. 146), "leaders must endeavor to learn to read emotional signals from individuals in order to address how to motivate at whatever level of concern could be most impacted. People will always have concerns, but determining which concerns within the workplace influence a personal need is key to providing the best motivation". The forth aspect must be taken into consideration by the leaders within the meaning of self-actualization, which is that with reference to the investigation on genders (Hall and Hansen, 1997), by seeking to compare self-actualizing individuals subject to their sex, women performed higher abilities of self-actualization, while men, on the contrary, were focused on satisfaction of other lower needs.

When analyzing self-transcendence, it is important to mention that individuals motivated by this factor, as it is showed by the investigation (Sagiv and Schwartz, 2007), performs higher level of tolerance, understanding and attentiveness, as well as democracy, respect, aspects of equality and moral dimension. First of all, this element may be relevant to the leaders, who seek to reduce corruptible behavior, dishonesty in the workplace, to improve information flow and to assure effective implementation of decisions. Secondly, self-transcendent individuals can be effectively directed to perform service provision functions. They may be the ones, who, because of their inner motivation, will endeavor to meet customer's needs by naturally taking them into account. According to the authors of the article, self-transcendent individuals may be very efficient in the field of human recourses. These workers can be used as a tool by the managers to improve organizational environment, thereby, reducing the staff migration trends. The third very important factor may be useful for the international organizations. Self-transcendence is attractive in multi-cultural environment, because self-transcendent individuals exposed higher level of honesty, positive attitude towards differences of age, race, gender and religion, comparing to the individuals, who were focused on self-individuality, what could refer to self-actualization within the context of the analyzed article. These facts are based on the research made by Olukemi (Olukemi et al., 2004).

The most interesting fact is that the elements of self-actualization and self-transcendence depend on culture and may influence behavior of customers. The investigation of Y. Cai and R. Shannon (2010, p. 290) revealed that "while Western mall shoppers are more likely to be directed by social affiliation and self-actualising values [...] Chinese mall shoppers are more likely to be influenced by self-transcendence". This implies that cultural dimension is related to distribution of the highest motivational needs. Nonetheless, the adjustment of the highest motivational needs depends on the leaders, the ability to use the workers properly, according 
to their personal characteristics by providing them opportunity to reveal themselves by highlighting their fortes in the direction of self-actualization and self-transcendence.

To sum up, both sides are relevant and may be useful for organizations. It is very important to choose proper directions of management according to the organizational blueprint, cultural field and demands.

\section{Conclusion}

The theoretical analysis revealed that F. Taylor's scientific management conception as well as traditional $\mathrm{M}$. Weber's bureaucratic organization conception a priori set lower components of later formed A.H. Maslow's motivation theory. It is worth noticing that there dominates the mechanical approach to the worker, depersonalizing him and considering him as a mechanism in both modernistic management models, that way there is no place to reveal neither self-actualization, nor self-transcendence.

Considering challenges which are raised by postmodern era, constantly changing competitive environment and customers' needs, organizations must provide an opportunity for the staff members to ensure the satisfaction of their lower needs while using opportunities which self-actualizing and self-transcendence offer.

The analysis of self-actualizing and self-transcendence elements revealed that tension between these two factors is artificial and generally it should not appear, considering that both elements imply a set of certain features and aspects, which can be fully beneficial for the organizations, however, it is required to direct individuals with these needs to suitable direction for them, assigning them to adequate positions, defining features which suit them the best.

It is essential to enable workers who self-actualize themselves to express their winning ambitions, compete, ensure greater freedom of action and raise more complex goals in their workplace.

Workers, who have the motivation factor of self-transcendence because of their orientation to others, stepping over personal boundaries, should be orientated to provide services, customer services, working in human resources, where their activities would be much more constructive.

\section{References}

Alderfer, C. P. (1972). Existence, Relatedness, and Growth: Human Needs in Organizational Settings. New York: Free Press.

Assor, A., and Oplatka, I. (2003). Towards a Comprehensive Conceptual Framework for Understanding Principals' Personal-Professional Growth. Journal of Educational Administration, 41(5): 471-497.

Cai, Y., and Shannon, R. (2012). Personal Values and Mall Shopping Behaviour: The Mediating Role of Intention among Chinese Consumers. International Journal of Retail \& Distribution Management, 40(4): 290-318.

Crumpton, M. A. (2013). Keeping the Motivation Going. Bottom Line: Managing Library Finances, 26(4): 144-146.

Hall, E. G., and Hansen, J. (1997). Self-Actualizing Men and Women - A Comparison Study. Roeper Review, 20(1): 22-27.

Henry, P. (2006). Magnetic Points for Lifestyle Shaping: The Contribution of Self-Fulfillment, Aspirations, and Capabilities. Qualitative Market Research: An International Journal, 9(2): 170-180. 
Hiriyappa, B. (2009). Organizational Behavior. Daryaganj, Delhi, IND: New Age International.

Maslow, A. H. (1972). The Farther Reaches of Human Nature. New York, USA: The Viking Press.

Maslow, A. H. (1943). A Theory of Human Motivation. Psychological Review, 50(4): 370-96.

Nordin, F. (2009). Transcendental Marketing: A Conceptual Framework and Empirical Examples. Management Decision, 47(10): 1652-1664.

Olukemi, O., Sawyerr, J. S., and Jun, Y. (2005). Individual Value Structure and Diversity Attitudes: The Moderating Effects of Age, Gender, Race, and Religiosity. Journal of Managerial Psychology, 20(6): 498-521.

Payne, R. L (2000). Eupsychian Management and the Millennium. Journal of Managerial Psychology, 15(3): 219-226.

Sagiv, L., and Schwartz, S.H. (2007). Cultural Values in Organisations: Insights for Europe. European Journal of International Management, 1(3): 176-90.

Tayeb, M. (2004). International Human Resource Management: A Multinational Companies Perspective. Oxford, UK: Oxford University Press.

Taylor, F. W. (1911). Shop Management, The Principles of Scientific Management and Testimony Before the Special House Committee. Harper \& Row.

Weber, M. (1978). Economy and Society: An Outline of Interpretive Sociology. Berkley, CA: University of California Press.

Wolfe, D. B., and Sisodia, R. (2003). Marketing to the Self-Actualizing Customer. Journal of Consumer Marketing, 20(6): 555-569.

Wright, M. (2009). Gower Handbook of Internal Communication. Abingdon, Oxon, UK: Ashgate Publishing Group.

\title{
SAVIRAIŠKOS IR SAVITRANSCENDENCIJOS DICHOTOMIJA
}

\author{
Ramūnas VANAGAS \\ Adomas Vincas RAKŠNYS \\ Mykolo Romerio universitetas, Lietuva
}

Santrauka. Straipsnyje demesys skiriamas klasikinei A. H. Maslowo motyvavimo koncepcijai, siekiant sintezuoti šios teorijos logiką su F. Tayloro ir M. Weberio valdymo teorijomis, pagrindžiant Maslowo motyvavimo teorijos kaip priemonès formuojant organizacinę kultūrą ir vertybes, kuriomis pasižymès personalo nariai, reikšmę. Antrojoje straipsnio dalyje gvildenama problema, susijusi su svarbiausiais Maslowo teorijos veiksniais - aukščiausiu, individualistiniu saviraiškos veiksniu bei altruistine, dvasingesne savitranscendencijos alternatyva, siekiant iškristalizuoti šių faktorių implikacijas organizacijų vadovams, suteikiant galimybę identifikuoti šias savybes personalo narių atžvilgiu bei ịvertinti abiejų faktorių teikiamą naudą lyderystės aspektu atsižvelgiant ị specifinį organizacijos veikimo lauką.

Reikšminiai žodžiai: saviraiška, savitranscendencija, poreikių hierarchija, motyvacija, Maslowas. 